\title{
Menimbang Perspektif Perennial Philosophy dalam Studi Lintas Agama: Potret Pemikiran Sayyed Hossein Nasr dan Frithjof Schuon.
}

\author{
Muhammad Haramain ${ }^{1}$ \\ Untuk-Nya yang tak terangkum oleh segenap kata, Tersingkap lewat ribuan sabda; \\ Untuk para pengabdi perangkai nada Abad ke-21: era kebangkitan agama-agama. \\ Dan peradaban masa depan akan ditandai oleh menonjolnya \\ pemikiran intelektual yang 'suprarasional' \\ dan kehidupan keagamaan yang 'suprareligius. \\ -Alvin Toffler-
}

\section{A. Pendahuluan}

Tantangan paling serius dalam kehidupan antar umat beragama sekarang ini adalah bagaimana seorang beragama bisa mendefinisikan dirinya secara tepat di tengah-tengah agama orang lain. Sebab, kenyataan menunjukkan bahwa pergaulan antar agama kini kian memperlihatkan intensitasnya. Sehingga tidak mengherankan jika banyak kalangan memandang zaman sekarang sebagai "zaman baru" (New Age), yang mencirikan pesatnya perhatian manusia terhadap dunia spiritual. Semboyan yang ditulis John Naisbitt dan Patricia Aburdene dalam Megatrends 2000, yang menyebut "Spirituality, Yes, Organized Religion, No", 2 menandai besarnya perhatian ini-khususnya dari Manusia Barat-terhadap spiritualitas Timur.

${ }^{1}$ Makalah ini dipresentasikan pada Seminar Kelas Mata Kuliah Studi Kritis Pemikiran Islam yang dipandu oleh Yang Amat Terpelajar, Prof. Dr. H. M. Nihaya, M.Hum. Pada hari Selasa 18 Nopember 2014 di PS UIN Alauddin Makassar

${ }^{2}$ Lihat John Naisbitt dan Patricia Aburdene, Megatrends 2000, Ten New Directions for the 1990's (New York: Avon Books, 1991), h. 295. 
Bila ditelusuri lebih jauh, semangat di balik semboyan Naisbitt-Aburdene itu, sesungguhnya telah lama dikenal di kalangan masyarakat tertentu, di Barat maupun Timur. Mereka ini menyadari perlunya spiritualisme dalam hidup manusia, namun mereka amat kritis terhadap agama-agama mapan, jika tidak ditolaknya sama sekali.

Kendati demikian menarik sekali mengkaji uraian Naisbitt-Aburdene mengenai kehidupan beragama di bawah semboyan tersebut. Sebab dari polling pendapat yang dikumpulkannya memperlihatkan adanya indikasi menaiknya spiritualisme di kalangan masyarakat Amerika, lebih tinggi dari masa-masa sebelumnya. Sejumlah besar dari mereka percaya bila "Tuhan adalah kekuatan spiritual yang positif dan aktif', meskipun gejala itu disertai dengan menurunnya peranan agama-agama formal. Kalangan muda terpelajar di sejumlah perguruan tinggi adalah yang pertama-tama bersikap sangat kritis kepada agama-agama formal. Mereka menilai gereja dan Sinagog "sibuk dengan masalah-masalah keorganisasian, dengan meminggirkan isu-isu teologis dan spiritual". Maka, demikian Naisbitt-Aburdene, mereka, kaum muda itu bukannya manusia "beragama" (religious) tetapi "berkeruhanian" (spiritual). ${ }^{3}$

Sedemikian besar perhatian masyarakat Barat terhadap kehidupan spiritualitas, sehingga pada akhir dasawarsa 1980-an terbit sebuah ensiklopedi besar yang sangat sarat pengetahuan spiritual di zaman arkaik, agama-agama, esoteris modern, hingga satu jilid berkaitan dengan pertanyaan sekuler atas keabsahan spiritualitas itu sendiri. Ensiklopedi yang berjudul World Spirituality: An Encyclopedic History of the Religions Quest ini berjilid 25, dua di antaranya tentang spiritualitas Islam yang diedit Seyyed Hossein Nasr. ${ }^{4}$

${ }^{3}$ Naisbitt-Aburdene. Megatrends 2000, h. 295-6.

${ }^{4}$ Seyyed Hossein Nasr adalah satu dari sekian pemikir perennialis terpenting dewasa ini. Pikiran-pikirannya yang kritis tersebar di pelbagai penerbitan ternama di Barat. Karena itu tak 
Sementara itu, satu masalah mendasar yang selalu menghadang adalah munculnya kebingungan-kebingungan teologis, khususnya bagaimana seseorang mesti mendefinisikan dirinya di tengah-tengah agama lain yang juga eksis dan punya keabsahan. Padahal, seperti diketahui bila teologi lama di set-up dan sejarahpun kemudian mengekstremkannya dalam suatu kondisi non pluralitas: bahwa hanya agama kitalah yang paling benar, sementara agama lain menyimpang. Belum lagi masalah-masalah sosial-politik yang sering tiba-tiba memunculkan ketegangan dan krisis di kalangan antar pemeluk keagamaan. Untuk fenomena terakhir dapat disaksikan pada peristiwa-peristiwa lokal belakangan ini, yang timbul di pelbagai kawasan.

Akan tetapi, satu hal yang membingungkan — baik secara teologis maupun epistemologis - adanya kenyataan yang menunjukkan bahwa agama lain juga memiliki klaim serupa, bahkan dengan tingkat kecanggihan teoretis yang tidak kalah rasionalnya. Pertanyaan yang muncul kemudian adalah: mungkinkah hidup rukun dan harmonis dapat terwujud dalam kehidupan antar umat beragamasementara pluralitas agama, pemikiran, budaya dan historisitas masing-masing agama - secara ketat dan dinamis bersentuhan dengan kehidupan mereka? Atau dengan ungkapan sebaliknya: mungkinkah pluralitas keagamaan dapat dipertemukan dalam sebuah kesadaran murni, terutama dalam merumuskan sebuah "kebenaran universal" demi terciptanya keharmonisan hidup di kalangan antar umat beragama?

sedikit yang memandang Nasr sebagai tokoh pemikir Perennialis yang cukup menonjol di samping deretan nama-nama penting lainnya seperti, Frithjof Schuon, Martin Lings, Marco Pallis, Huston Smith - untuk sekedar menyebut beberapa di antaranya. Perhatiannya yang sangat serius dan intens terhadap kehidupan spiritual serta tawarannya tentang perlunya dialog intra-iman di kalangan pemeluk Agama dan Tradisi besar, memposisikan dirinya sebagai Tokoh Tradisionalis - satu term yang dikenalkannya sendiri sebagai satu bentuk pemikiran yang berorientasi kepada "Tradisi" yakni kehidupan Primordial sebelum manusia diciptakan. Karya-karya terpenting Nasr untuk jenis pemikiran ini antara lain; "The Philosophia Perennis and Study of Religion" (1984), Traditional Islam in the Modern World (1988), Knowledge and The Sacred (1989), Sufi Essays (1972), Islamic Art and Spirituality (1990) dan The One in The Many (1993). 
Setidaknya terdapat dua jawaban atas pertanyaan itu. Pertama, mereka yang bersikap pesimistik. Kalangan ini melihat aadanya kesulitan teologis ataupun epistemologis untuk mempertemukan pelbagai keyakinan yang ada. Sebab bagi masing-masing pemeluk agama, tidak semata terletak pada rumusan tapi juga substansi kebenaran mereka berbeda secara radikal. Sementara kelompok kedua, lebih terbuka, optimistik dan karena itu pula lebih bersifat dialogis. Kelompok terakhir ini, mengajak pelbagai bentuk agama dan tradisi yang otentik agar memiliki visi "universal" dalam merumuskan apa yang dalam filsafat disebut the meaning and the purpose of life (makna dan tujuan hidup). Itu sebab, dalam konteks ini perjumpaan berbagai bentuk keagamaan yang terpenting tidak pada dataran formalnya (eksoteris), namun lebih ditekankan pada aspek “dalam” (esoteris)nya. Karena menurut keyakinan kelompok ini, hanya dengan melepaskan klaim-klaim kebenaran dan penyelamatan yang berlebih, mengoreksi diri tentang standar ganda yang sering dipakai menghakimi agama lain dan selanjutnya memperluas pandangan inklusif teologi, barulah agama-agama akan mempunyai peran penting di masa depan, khususnya dalam upaya membangun dasar spiritualitas peradaban umat manusia.

Berangkat dari kesadaran untuk mendialogkan agama dari daratan substansinya, di mana agama pada dasarnya dipandang sebagai relatively absolute (hanya secara relatif absolut), atau jika dibalik absolutely relative atas klaim-klaim kebenaran yang secara tradisional memang inheren dalam agama maka agama bisa diharapkan kembali seperti sedianya mengambil peran pembebasan (interior dan eksterior) atas kemanusian. Perspektif yang terakhir inilah yang dikenal belakangan sebagai Filsafat Perennial. ${ }^{5}$

${ }^{5}$ Budhy Munawar-Rahman. "Pengantar", h. xxviii. 
Dari uraian tersebut di atas, serta merta sebuah pertanyaan tersebut: seberapa jauhkah relevansi Filsafat Perennial (Sophia Perennis) sebagai sebuah perspektif dalam studi lintas agama kini dan di masa depan? Dari sini dapat dikemukakan sejumlah pertanyaan kunci: pertama, Apa landasan konseptual dan epistemologi Filsafat Perennial? Lalu sebagai sebuah perspektif, dimanakah letak signifikansi filsafat ini bagi pengembangan studi lintas agama di masa depan? Kedua, Sejauh manakah relevansi dan signifikansi Filsafat Perennial terhadap kehidupan beragama di Indonesia, khususnya bagi perumusan resolusi konflik antar umat beragama yang belakangan kian menampakkan intensitasnya di tanah air.

\section{B. Menimbang Perspektif Filsafat Perennial}

Mengawali tulisan ini, sangat perlu agaknya mempertegas apa yang dimaksud dengan "Filsafat Perennial" (philosophia perennis) atau terkadang juga disebut "Kebijaksanaan Perennial" (sophia perennis). Meski demikian kedua kata itu tidak sepenuhnya identik: yang pertama lebih bersifat intelektual, sementara yang kedua lebih merupakan aspek perwujudannya. ${ }^{6}$

Filsafat Perennial (perennial philosophy) adalah istilah Inggris untuk arti yang sama dengan philosophia perennis yang berasal dari bahasa Latin, telah digunakan secara luas oleh aliran-aliran pemikiran, dari kaum neo-Thomis hingga Aldous Huxley. Bahkan nama terakhir ini membuat istilah "Filsafat Perennial" demikian populernya di kalangan banyak mahasiswa yang bukan spesialis dalam studi agama dan filsafat, karena ia menggunakan istilah tersebut untuk judul

\footnotetext{
${ }^{6}$ Tentang term "Filsafat Perennial" dan sejarah penggunaannya, lihat S.H. Nasr Knowledge and the Sacred, (New York: 1981), h. 68.
} 
bukunya The Perennial Philosophy, yang terkenal itu. ${ }^{7}$ Karena demikian luasnya istilah itu digunakan sehingga perlu dijernihkan dalam konsteks studi ini.

Sedangkan Frithjof Schuon ${ }^{8}$ mengungkapkan bahwa Filsafat Perennial adalah, "The timeless metaphysical truth underlying the diverse religions, whose written sources are the revealed scriptured as well as the writing of the great spiritual masters".

Dengan begitu, Filsafat Perennial memperlihatkan kaitan seluruh eksistensi yang ada di alam semesta ini dengan Realitas Mutlak. Wujud pengetahuan tersebut dari dalam manusia hanya dapat dicapai melalui Intelek - istilah yang telah dikenal sejak zaman Plotinus lewat karyanya The six Eneads—sebagai ungkapan lain dari soul atau Spirit. "Jalan" inipun hanya dapat dicapai melalui tradisi-tradisi, ritusritus, simbol-simbol dan sarana-sarana yang memang diyakini oleh kalangan parennial ini sebagai berasal dari Tuhan.

Sesungguhnya, dasar-dasar teoretis pengetahuan Filsafat Perennial terdapat dalam setiap agama yang otentik, yang dikenal dengan berbagai konsep: dalam Agama Budha misalnya disebut Dharma, dalam Taoisme disebut tao, dalam Hinduisme dikenal sebagai Sanathana atau dalam Islam dikenal dengan konsep alDîn, dalam filsafat Abad Pertengahan dikenal dengan sebutan sophia perennis dan sebagainya. Dengan cara-yang dalam Filsafat Perennial disebut sebagai “transenden" itu-semua ritus-ritus, doktrin-doktrin dan simbol-simbol

${ }^{7}$ S.H. Nasr, "The Philosophia Perennis and Study of Religion" dalam Frank Whaling (ed), The World's Religious Traditions, Current Perspectives in Religious Studies Essays in Honour of Wilfred Cantwell Smith (Edinburg: T \& T Clark Ltd., 1984), h. 182.

${ }^{8}$ Frithjof Schuon adalah tokoh terpenting yang sering dipandang sebagai genius terbesar filsafat ini di abad 20, dalam semua bukunya mencoba menguraikan keruwetan doktrin-doktrin metafisika dari berbagai tradisi agama-agama itu. Buku-bukunya yang mencerminkan jenis perspektif filsafat ini antara lain : Logic and Transcendence (1975), Islam and The Perennial Philosophy (1976), From Divine to the Humen : Survey of Metaphysics and Epistemology (1982), Survey of Metaphysics and Esoterism (1986), The Transcendent Unity of Religiuos (1975), Christinity/Islam : Essays on Esoteric Ecumenicism (1981), dan Echoes of Perennial Wisdom (1992). 
keagamaan yang dipakai untuk mencapai pengertian mengenai dasar keagamaan itu, mendapatkan penjelasan yang menyeluruh melewati bentuknya yang formal. ${ }^{9}$

Dari uraian tersebut dapat dipahami bahwa Filsafat Perennial adalah satu perspektif yang memandang adanya "kesatuan transenden" atau "kesatuan spiritual" pada setiap agama dan tradisi otentik. Perspektif ini, tidak semata mengedepankan aspek-aspek "dalam" (esoteris) dari setiap bentuk keagamaan, tapi juga punya kemampuan mengeliminir sejumlah perbedaan eksternalitas agama. Meskipun demikian, tidak dengan sendirinya berarti Filsafat Perennial berpandangan bahwa "semua agama adalah sama": Suatu pandangan yang sama sekali a-historis dan tidak menghormati religiusitas yang partikular. Sebaliknya, Filsafat Perennial justru berpandangan bahwa Kebenaran Mutlak (The Truth) hanyalah satu, tidak terbagi. Tetapi dari yang Satu ini memancarkan berbagai "kebenaran" (truths) sebagaimana halnya matahari yang secara niscaya memancarkan cahayanya. ${ }^{10}$

Dengan mengembangkan perspektif transendental ini ditemukan kemudian adanya norma-norma abadi yang hidup dalam jantung setiap agama-agama besar maupun tradisi-tradisi spiritual kuno. The heart of religion inilah yang bersifat Ilahi dari agama-agama itu serta menjadi kajian serius_-dan pada urutannya diyakini lalu disiarkan-oleh kaum perennialis. Dengan kata lain, upaya transendenmetafisis inilah yang diyakini oleh kalangan perennialis sebagai "kunci" agar manusia dapat memahami ajaran agama-agama yang sangat kompleks dan penuh

${ }^{9}$ Budhy Munawar-Rahman, "Pengantar", h. xxix.

${ }^{10}$ Tentang bentuk-bentuk "kebenaran" (truth) sebagai manifestasi iluminatif dari Yang Maha Benar (The Truth), menarik mengutif ilustrasi F. Schuon: "Jika A melihat cahaya merah dan B melihat cahaya biru, bukanlah merupakan pandangan yang lemah jika dikatakan keduanya melihat cahaya". Hal yang sama mungkin dapat pula diterapkan pada pernyataannya yang lain: "apa yang benar bagi kita, harus benar secara universal, karena itulah arti kebenaran". Lihat, Huston Smith "Introduction", dalam Frithjof Schuon, The Transcendent Unity of Religions (New York: Herper \& Row, Publisher, 1975), h. xiii. 
misteri yang tak pernah dapat diselami maknanya lewat analisis empiris apalagi historis sebagaimana yang dilakukan oleh para sarjana agama-agama selama ini. Karena itulah, kajian tentang Filsafat Perennial tidak saja menawarkan perspektif alternatif bagi studi agama di masa depan yang dekat, tapi juga kian memperlihatkan signifikansinya sebagai wacana dialog intra-religius di kalangan umat beragama yang pada urutannya diharapkan mampu menjadi resolusi konflik antar umat beragama di tanah air.

Meski demikian, tidak dengan sendirinya berarti Filsafat Perennial sunyi dari kritik. Sebut saja misalnya para ahli agama yang tidak percaya akan adanya "kesatuan transenden", memandang Filsafat Perennial sebagai sesuatu yang tidak ada dan hanya merupakan imajinasi dari para penganut Filsafat Perennial saja. Apalagi jika secara empiris mereka hanya mampu melihat pertentanganpertentangan yang terdapat dalam agama-agama sementara mereka tidak mau melihat adanya the common vision dari agama dan tradisi yang otentik tersebut.

F. Zaehner umpamanya, sebagai seorang Kristen yang ahli Hindu dan Sufi menyebut, alih-alih kesatuan, justru lebih banyak pertentangan dalam agama yang satu dengan yang lain. Di kalangan tradisional Islam juga tidak sedikit yang menolak gagasan "kesatuan transenden" ini, seperti Seyyed Naquib al-Attas. Pada hal dengan Filsafat Perennial ini-tentu saja bagi penganut filsafat ini-disadari adanya "yang Infinite" di balik kenyataan ini (levels of Reality [alam terrestrial, intermediate, celestial]). Juga dalam diri manusia-yang dalam Filsafat Perennial disebut levels of selfhood - terdiri dari body, mind, soul, atau dalam istilah Islam, jasad, nafs, dan 'aql dipercayai adanya apa yang disebut "Spirit" (Ruh). Alam semesta (macrocosmic) dan manusia (microcosmic) pada dasarnya memiliki ikatan 
"persaudaraan kosmik" dan karena itu tak lebih sebagai tajalli atau bentuk perwujudan dari Yang Infinite/Spirit ini, yang dalam Islam disebut al-Haqq. ${ }^{11}$

Karena kepercayaan akan adanya levels of Reality dan levels of Selfhood, maka para penganut filsafat ini mempercayai adanya dunia yang bersifat hirarkis (bertingkat-tingkat). Huston Smith dalam bukunya The Forgotten Truth (1992) menyebut tingkat-tingkat ini sebagai the great chain of being (mata rantai agung seluruh keberadaan). Atau E.F. Schumacher yang menyebutkan dengan istilah the hierarchy of existence (tingkat-tingkat eksistensi), mulai dari Tuhan pada peringkat tertinggi hingga manusia dan makhluk-makhluk/benda-benda "di bawah" manusia. Atau sebaliknya dari benda-benda mati pada tingkat paling rendah, hingga Tuhan pada tingkat paling tinggi.

Dari sudut pandang hirarkis atau tingkat-tingkat eksistensi inilah diberikan argumen bahwa "tradisi" adalah jalan yang memberitahu kita bagaimana menempuh pendakian dari tingkat eksistensi/realitas yang lebih rendah-yaitu kehidupan sehari-hari ini-sampai ke tingkat/realitas yang paling tinggi; kepada Tuhan melalui pengalaman-pengalaman mistis, pengalaman kesatuan atau wahdat al-Wujud dan pengalaman-pengalaman spiritual lainnya.

\section{Anatomi Kehidupan Beragama di Indonesia: Perspektif Filsafat Perennial}

Memahami agama, mestinya tidak sebatas pada pemahaman agama secara formal (eksoterik). Tetapi, agama harus dipahami sebagai sebuah kepercayaan, dimana ketika orang memahaminya akan toleran kepada pluralisme, dan tidak arogan terhadap agamanya sendiri. Amat disayangkan, selama ini orang memandang agamanya sebagai klaim kebenaran tunggal dan paling baik. Sementara agama lain mengalami reduksionisme, karena itu tidak benar dan kurang

\footnotetext{
${ }^{11}$ Lihat Budhy Munawar-Rahman, "Pengantar", h. xxxi-ii.
} 
sempurna. Sikap ini lantas memunculkan hegemoni agama formal, sedemikian rupa sehingga agama lokal, agama suku, atau pun agama kecil terpinggirkan oleh agama formal.

Kedangkalan pemahaman agama secara esensial (esoterik) ini, pada urutannya menyebabkan kurangnya toleransi dan maraknya konflik. Ada ketakutan dengan "dialog agama", "dialog antar iman" dan "dialog antar spiritual” dikalangan pelbagai bentuk agama dan tradisi yang otentik, sehingga pemahaman itu tidak subtansial dan mendalam. Itu pula sebabnya mengapa sementara pihak memandang begitu penting mengembangkan asumsi semua agama mengajarkan kebijakan, kemuliaan, kedamaian, keharmonisan. Bukan mengajarkan kedurjanaan, kekerasan, dan kejahatan. Dalam konteks ini, agama atau kepercayaan ruhani yang paling batin, dengan sendirinya mesti terlepas dari kategorisasi: agama wahyu atau tidak, karena hal itu tidak lagi relevan. Ketika ada klaim bahwa satu agama adalah "agama wahyu" atau "agama langit" sementara yang lainnya bukan, maka yang muncul kemudian ialah arogansi dan memposisikan agamanya yang paling sempurna. Itu sebab, menjadi signifikan memahami “Agama itu Agama”. Sehingga pada saat itu terjadi dialog, yang muncul ialah "kesejajaran" dan bukannya arogansi yang menepikan argumentasi. Kendatipun demikian, hal ini tidak dengan sendirinya berarti bahwa agama formal dengan demikian tidaklah penting. Sebab, satu hal yang tak dapat dipungkiri bahwa, keimanan tanpa suatu bangunan formal adalah sakit. Sehingga, pemunculan esoterik disini tak lebih dari sekadar upaya sadar bahwa tema tersebut memiliki posisi yang sejajar dengan eksoterisme dalam mengkaji suatu agama.

Karena itu-seperti telah berulang-ulang kami uraikan dalam bab-bab terdahulu-bahwa filsafat perennial tidak sekali-sekali menafikan makna dan fungsi eksoterisme (formal) dalam menghayati dan melaksanakan ajaran agama. Bahkan, 
tanpa dimensi eksoterisme agama akan kehilangan relevansi dan daya emansipasinya bagi manusia dalam membangun peradaban dan dalam mengatasi persoalan hidup yang bersifat institusional dan empiris. Di sinilah, sekali lagi, eksoterisme menjadi satu tema yang tak kalah pentingnya dari kajian esoterisme. Tradisi perennial memang selalu meningkatkan dualisme agama-bukannya dualisme-antara eksoterisme dan esoterisme, namun keduanya tetap merupakan satu kesatuan yang integral. Ibarat sebuah koin yang memiliki dua sisi: ia tak dapat dipisahkan tetapi jelas dapat dibedakan. ${ }^{12}$

Esoterisme, yang secara intrinsik memang sudah dengan sendirinya bersifat universal dan karenanya sangat terbuka, meniscayakan pluralistas eksistensi agama. Pluralitas eksistensi agama, yang kita sebut kemudian sebagai eksoterisme agama, karena tidaklah serta merta dianggap sebagai suatu kesatuan yang terkutuk, melainkan sebagainya merupakan keharusan penjelmaan historis dari esensi agama yang bersifat esoterik. ${ }^{13}$

Dalam perspektif filsafat perennial ditegaskan bahwa kebenaran abadi yang universal akan selalu ditemukan pada setiap agama, meskipun masing-masing tradisi agama memiliki bahasa formalnya yang berbeda-beda. Karena peradaban format inilah maka kesulitan, konflik dan bahkan konfrontasi antar pemeluk agama seringkali muncul ke permukaan. Pada tahap ini, agama muncul dalam bentuknya yang beragam dengan "bahasa agama" yang bervariasi pula, sementara kita cenderung melihat perbedaan itu pun sepenuhnya salah. Malahan terdapat kemestian seorang beriman untuk meyakini dan membela kebenaran yang dipeluknya, berdasarkan pengetahuan dan trasisi yang dimilikinya. Dan sikap

\footnotetext{
${ }^{12}$ M. Sabri, Filsafat Perennial: Perspektif Alternatif Bagi Studi Agama dan Signifikansinya Terhadap Kehidupan Beragama di Indonesia. Tesis. PPS IAIN Sunan Kalijaga, 1997. (Tidak dipublikasikan)

${ }^{13}$ Komaruddin Hidayat dan Muhammad Wahyuni Nafis, Agama Masa Depan: Perspektif Filsafat Perennial, (Jakarta: Paramadina, 1995), p. 96.
} 
seperti ini absah saja jika bukannya terpuji, sepanjang tidak menimbulkan situasi sosial yang destruktif.

Itu pula sebabnya, sehingga Komaruddin Hidayat ${ }^{14}$ menyatakan bahwa kecenderungan eksklusivisme itu memang suatu yang secara intrinsik dimiliki pada tahap keberagaman eksoterisme, dan secara psikologis seorang akan lebih mudah memberikan afirmasi terhadap kebenaran agama yang dianutnya antara lain dengan cara menegasikan atau menyalahkan kebenaran agama orang lain. Dari pandangan seperti inilah tampaknya, pelbagai macam konflik dan konfrontasi antar pemeluk agama itu muncul.

\section{Penutup}

Dalam konsteks ini tampak kian tegas bahwa salah satu tema terpenting dalam kajian Filsafat Perennial adalah the transcendent unity of religions atau "kesatuan transenden agama-agama". Dari perspektif ini dapat dipahami bahwa Filsafat Perennial menawarkan satu bentuk interaksi antar pemeluk umat beragama yang lebih bersifat substansial, sejuk, dialogis dan di atas segalanya berada dalam "wacana" spiritual.

Dengan kata lain, perspektif Filsafat Perennial terbangun di atas sebuah paradigma bahwa semua agama dan tradisi yang otentik berasal dari Tuhan Yang Satu. Meskipun dalam perjalanan historisitas umat manusia didapati pelbagai bentuk keagamaan dan tradisi, tetapi Filsafat Perennial memandang bahwa semua “jalan kebenaran” berawal dan berakhir pada Kebenaran Tunggal, yaitu Tuhan.

\footnotetext{
${ }^{14}$ Komaruddin Hidayat, Ibid., p. 70.
} 


\section{REFERENCES}

John Naisbitt dan Patricia Aburdene, Megatrends 2000, Ten New Directions for the 1990's (New York: Avon Books, 1991)

Frithjof Schuon, The Transcendent Unity of Religions (New York: Herper \& Row, Publisher, 1975)

Haramain, Muhammad. "DAKWAH DALAM ARUS GLOBALISASI MEDIA: PELUANG DAN TANTANGAN." KOMUNIDA: MEDIA KOMUNIKASI DAN DAKWAH 7.1 (2017): 60-73.

Haramain, Muhammad. "الوسطية وأثرها فى الدعوة الإسلامية (دراسة لغوية منهجية)" Langkawi: Journal of The Association for Arabic and English 2.1 (2016): 83-100.

Ulum, Ahmad Choirun, and Muhammad Haramain. "EKSISTENSI DAKWAH DALAM MERESPON PLURALISME." KOMUNIDA: MEDIA KOMUNIKASI DAN DAKWAH 7.2 (2017): 124-138.

Hidayat, Komaruddin. dan Muhammad Wahyuni Nafis, Agama Masa Depan: Perspektif Filsafat Perennial (Jakarta: Paramadina, 1995).

Nasr, Seyyed Hossein. "The Philosophia Perennis and Study of Religion" dalam Frank Whaling (ed.), The World's Religious Traditions, Current Perspectives in Religious Studies Essays in Honour of Wilfred Cantweel Smith, (Edinburg: T \& T Clark Ltd., 1984). , Islam and the Plight of Modern Man, (London: Longman, 1975). , Knowledge and the Sacred, (Edinburgh: Edinburgh University Press, 1981). , Traditional Islam in the Modern World, (Kuala Lumpur: Foundation for Tradition Studies, 1988). 